\title{
"Me and Libraries"
}

T HAve Always Had an interest in books. When I was a boy I was something 1 of a bookworm, in part because my eyesight kept me out of a good many games and sports. About the only thing they ever used me for in a back-lot ball game was to be an umpire. They did that because I couldn't see, and I think a lot of umpires are in the same fix today.

When I was about seven or eight years old, maybe ten, my mother purchased a set of books, four great big volumes that are down in my Independence library now. They are called The Lives of Great Men and Famous Women. They cover all of that modern history which was not covered by Greene and Guizot and those people. My mother used to sit up and read poetry to my brother, my sister, and myself. She would read Tennyson, or Shakespeare, or Robert Burns. (Sometimes we had a terrible time trying to understand what Bobby was talking about, but it made mighty musical reading anyway.)

And I used to read myself. By the time I was twelve or fourteen years old I had read every book in the Independence Library, including the encyclopedias, and-believe it or not-I happen to remember some. I really did read practically all the books. Those books had a great influence on me. Some that I remember were lives of the great men of history. In addition to all of those historical things there were a great many other books in the Independence Library, and there were some books I read which weren't there, certain paperback books which sold for a nickel apiece. They were called "Diamond Dick's," and they were right good. And I read western stories about the great John C. Fremont, "Buffalo Bill," "Wild Bill" Hickok, and all of the rest of them. You see, even when there were not any good, hard-bound books available, we always managed to find something to read-up in the barn, if we couldn't read it anywhere else.

You can see I owe a great deal to the public library of the City of Independence, and to public libraries in general. I have always had a great deal of respect and admiration for the men and women who work in libraries and who make the knowledge and the experience contained in the world of books available to the public. Along with the teachers of our youth, you perform a very great public service.

It was a great many years ago that I first knew a public library. The public

"Me and Libraries" is adapted from the address made by President Harry S. Tru- man at the ALA conference in Kansas City, June 27, 1957. 
library movement has grown and flourished since that time so that now, I understand, there are not nearly enough libraries and trained librarians to meet the demand. Libraries are one of the fine things of this country. Even one of our old "pirates" who made so many millions he didn't know really how much he was worth, when his conscience got to hurting him, began to give out libraries. I'll say to you that was a very great thing. It awakened a great many communities that otherwise wouldn't have one to the necessity for a library.

I was very sorry to hear that the appropriation for the Library Services Act had been cut in the Congress of the United States from an authorization of seven and a half million dollars to three millions, but the men who are interested in the education of the country and in the welfare of the library part of that education have succeeded in getting it back to five. There were a half-dozen Senators when I was there (and most of them are still there) who were vitally interested in the education of the country. Education is the fundamental basis on which a free government is founded. When people know the facts, when they know what's going on, when they understand just what the meaning of this and that is, you can be very sure that they usually do the right thing. I think I conclusively proved this in 1948.

Anything I can do to help in the affairs of education for the welfare of the rising generation, that's what I am going to spend the rest of my life trying to do. I am going to tell the coming generation that this government, the greatest government in the history of the world, is theirs, that they are responsible for it. We talk about the power of the government. It's in the individual. That's what makes our country great. When you as an individual neglect your rights as a citizen to see that you get the right sort of government, you get just what's coming to you. I don't feel sorry for you a bit. When you sit around and howl about the government and then fail to go vote, it's your own fault.

I want our younger generation-these youngsters in high schools or the first year or two of college-to understand what a fine government they have. And I'm in the position (I'm bragging a little bit now) to tell them just exactly what they have. I've had everything in the gift of the people from precinct to Presidency, and what more experience do you want if you want to find out about the government? I'm here to tell them about it.

I am vitally interested in what you are doing. One of the greatest assets this country has is its free public libraries. I want to see as many of them as possible. I want to make them accessible to the people who can use them. It's terribly hard for a man who works all day to go way into the center of town to get a book he wants to read. He ought to be able to go across the street and get it. That's what I hope you all work for. I'll help you all I can. I don't know that it will amount to much because my situation now is just that of a retired farmer from Missouri. I don't have much influence any more, but if I have any, it's going to be centered on aid to education and to the welfare of the rising generation so that they can appreciate what they have.

It's an interesting situation to study what a President of the United States has to do. It is the most powerful and the greatest office in the world. There was never a dictator nor an emperor who has shouldered such responsibilities as the President of the United States. I don't care who is President, he's going to have my sympathy as long as I live, because I know what he is up against. I want the rest of you to feel exactly the same way. It's your country and your government. One of the beautiful things about this most powerful job in the his- 


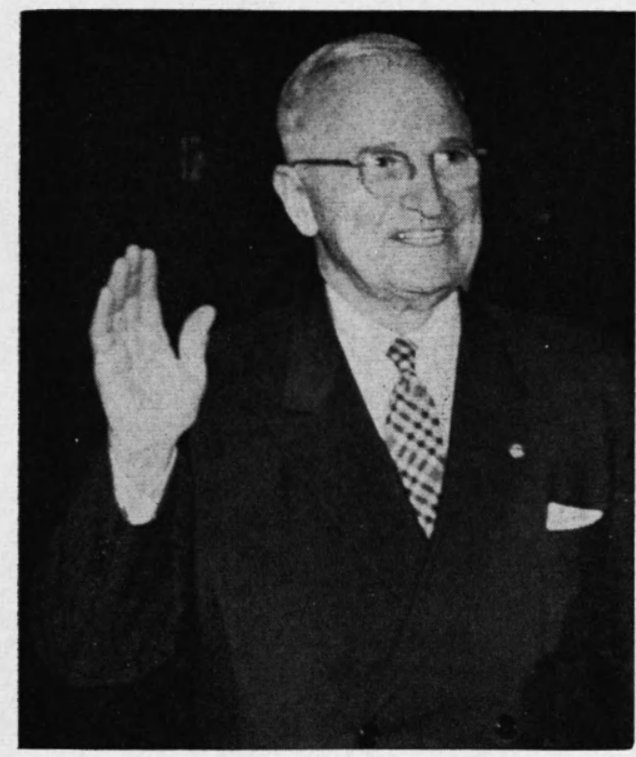

tory of the world is that it is the gift of you and you and you, the gift of the people; that's what makes it so fine.

If you think it's a cinch job-well, just to give you one instance: The last year we were in the White House-(We moved back there, you know, after it was rehabilitated. It was just about to fall down. The architects said it was standing up there only from habit, that it should have fallen down a long time ago. That's a fact. You never saw anything like it. Those old beams were rotten and ready to fall down.) Well, as I started to tell you, there are receptions, and people come for the purpose of taking a look at the animal who occupies the White House. There were fifty thousand people, by count, with whom Mrs. Truman had to shake hands. I shook hands with twenty-five thousand and dodged the rest, but she couldn't get out of it. Somebody had to do it. That gives you just one instance in which the President is burdened. It used to be they would have New Year receptions at the White House, and sometimes the President would stand and shake hands with five thousand people. They found they couldn't do that, and they don't do that any more. What they do is certainly enough.

But the President's life is not all troubles. He can have just as much fun as the rest of you, always remembering that everything he does has to be done for the interest of the country. After he is elected he represents all of the people of the country. He is the head of his political party, but as President of the United States he has to represent everybody as best he can.

The next time any of you is here, I trust you will make a special point to come out and take a look at that institution over in Independence that is known as my library. I'll be out there myself, and, as usual, my door won't be slammed in your face. If you want to come in and waste my time, I'll be glad to waste yours and look at the library with you. I like an interval once in a while, and I like to talk to people.

This library is not primarily a library of books. It is essentially a library of archives-historical documents - a place to preserve and make available the files and records of the Presidency as it went along during the time I was there.

It will also contain a great many other things. I have a tremendous number of records of a certain Senate committee which was known as the Committee to Investigate the National Defense Program. The chairmanship of that committee got me into all sorts of trouble. I wound up by being the presiding officer of the Senate and, finally, going to the White House. If I hadn't spent so much time on that committee, I'd still be in the Senate, and that's where I'd rather be than anywhere else in the world.

In addition to those Senate records there are a great many records of county government here in Jackson County. For ten years I was the presiding officer of the administrative end of the government of Jackson County which, at that time, 
had about four hundred thousand people in it. There are some most interesting things in the transaction of the business for a county. There isn't much difference in the transaction of county business and state business and the national business. It's just on a larger scale as you go along. The same problems come up. You have the same troubles.

And, of course, we have a collection of books to assist the students in the use of the records in the library. I'm contributing my own collection of books, some ten thousand of them, and we expect to build up a first-class collection of reference works and background works on the institution of the Presidency and on the foreign policy of the United States.

These records of the Presidency are the greatest set of historical documents this country produces. I am hoping that one of the great foundations will make a contribution for the study of the Presidency.

The Congress has a record. It's called The Congressional Record, and it is distributed to all the libraries in the country. It's supposed to set down just exactly what the members of the Senate and the House say when they are transacting business, but I want to whisper to you on the side that when a fellow gets up and makes an off-hand speech on the floor of the Senate or the House, the record is always brought in, and he corrects it so it looks like it really is all right. (It is, in most instances.) I'm speaking from experience. I've done that myself, so I'm not telling on anybody.

But there is no official record of the Presidency. The precedent was established by President Washington that a President's papers are private property. George Washington took all of his papers down to Mount Vernon. They were later sent to Boston to be worked on, and when they were finally returned a great many of them had been lost.

A lot of us from the Senate were inter- ested in preserving these records of the Presidency. There was a Congressman from New York City who never had any trouble getting elected [Sol Bloom]. He had a sure-thing district. And he spent his time having the Washington papers printed and indexed. It was a wonderful thing for him to do because it awakened people to the fact that these things ought to be looked after and taken care of. I was making a speech one day in his district in New York. Sol, of course, spent his time talking about George Washington all the time and rode his hobby to death. After my speech one of the old Nestors of his district said to me, "I'm well acquainted with Sol, but who the dickens is this fellow Washington he's always talking about?" Well, it's a laughable matter, but I say to you it is historical documents that are the record of the Presidency. Not taking care of them will leave a great many of us people will know nothing about in generations to come.

Now, the papers of Millard Fillmore were deliberately burned by his son. Half the papers of Abraham Lincoln were burned by Robert Lincoln. If it had not been for Nicholas Murray Butler catching him at it up at his summer resort in New Hampshire nearly all of Lincoln's papers would have been destroyed. Now that's not the proper thing.

There are sixteen or eighteen sets of Presidential papers in the Library of Congress. I have been before a House committee in support of a bill which authorizes the indexing and the microfilming of those Presidential papers and the other Presidential papers scattered over the country.

President Hoover's papers are taken care of in a library at Leland Stanford University in Palo Alto. President Roosevelt's papers are in a library at Hyde Park which he set up. The Adams Papers have been in the Adams Library back in Quincy, Massachusetts, for a long time. 
I've been going up and down the country promoting proper care of Presidential papers, and I've been saying that the Adamses made a living off those papers for 130 years. Believe it or not, they have now turned them over to Harvard to be indexed.

While I was in the Presidency Princeton University made up its mind to do something with the Jefferson Papers. Jefferson had the most orderly set of papers of any President. His grandnephew and grandniece became hard up, as descendants always do, and tried to sell these papers to the government of the United States. You know what Congress did? They said they would make a survey and they'd take all the official papers and not take the rest of them. They spent twenty years trying to find out which the official papers were. Finally they took half the papers, and these are in the Library of Congress. The rest of them are scattered from one end of this country to the other. (This kind of thing, you know, makes a field day for dealers in autographs with the papers that are not taken up, for any paper that the President has anything to do with is an offcial paper; it doesn't make any difference what it is.) Well, Princeton University is spending two or three hundred thousand dollars now reassembling the Jefferson Papers. They are having them printed in book form as Sol Bloom did George Washington's papers. I was present when the first volumes came off the press. I have the Number One volume and General Marshall has the Number Two volume of the Jefferson Papers. I value mine very highly.

I sincerely hope you will support me in my effort to see that the papers of the Presidents of the United States are properly cared for. That's the main reason I've been trying to establish this educational institution, this library, out here in Independence, Missouri. Another reason is to let those people east of the
Appalachian Mountains know that there are people in that part of the country between the Appalachian Mountains and the Rocky Mountains who are just the finest people in the world. One time when we thought the capital of the United States was going to be bombed, some of us got together and we were going to have an auxiliary capital at Colorado Springs so when those east came across the country to see it they would have to go through the best of the country. A lot of those people back east still have the idea that we have horns and a tail out here. I want you to go back and tell them that it's just not so.

In any case, if any of you are in the neighborhood, come on out to Independence and you'll find out what this library is for. And I hope, then, you'll get in the bandwagon with me and help us get some more support and get all these Presidential papers taken care of. Then you can say to the students, "Now if it's this you want to find out about, it's in this library." You will know it's under this President or that President, or it's under this Congress or that Congress, and you can tell them what they ought to do.

There ought never to be anything of any sort to stand in the way of education.

You don't know how much I appreciate your insisting on my coming over here tonight. But I'm rather tired tonight. I have to admit it. I don't admit it to the madam, but I'm admitting it to you. I've been working like everything all day. I have a tremendous day ahead of me tomorrow and for the rest of this week and all next week trying to get ready for the dedication of my library. I'm going to have a tremendous affair out here on the sixth of July. I am more than happy that you have been so kind and cordial to me. With your permission, I am going to bow myself out and go home and go to bed.

Thank you very much. 